Cornell Law Library

Scholarship@Cornell Law: A Digital Repository

Cornell Law Faculty Publications

Faculty Scholarship

$12-1963$

\title{
Security Interests in a Retail Merchant's Inventory: California Amends the Uniform Commercial Code
}

Robert S. Summers

Cornell Law School, rss25@cornell.edu

Follow this and additional works at: http://scholarship.law.cornell.edu/facpub

Part of the Commercial Law Commons, and the Secured Transactions Commons

\section{Recommended Citation}

Summers, Robert S., "Security Interests in a Retail Merchant's Inventory: California Amends the Uniform Commercial Code" (1963). Cornell Law Faculty Publications. Paper 1138.

http://scholarship.law.cornell.edu/facpub/1138

This Article is brought to you for free and open access by the Faculty Scholarship at Scholarship@Cornell Law: A Digital Repository. It has been accepted for inclusion in Cornell Law Faculty Publications by an authorized administrator of Scholarship@Cornell Law: A Digital Repository. For more information, please contact jmp8@cornell.edu. 


\title{
Security Interests in a Retail Merchant's
}

\section{Inventory: California Amends the Uniform Commercial Code}

\author{
ROBERT S. SUMMERs*
}

When the California Legislature at its 1963 session enacted the Uniform Commercial Code, ${ }^{1}$ it added section 9ro2(4), ${ }^{2}$ which significantly restricts the power of a retail merchant to create security interests in his inventory. ${ }^{3}$ Not one of the twenty-seven other states enacting the Code has similarly amended it. ${ }^{4}$ My aims in this brief Comment are ( $\mathrm{I}$ ) to outline the present California law governing the creation of security interests in the inventory of retail merchants, (2) to discuss the impact of section 9ro2(4) on this law, (3) to explain the effect on this law of enacting the Code without section 9ro2 (4), and (4) to consider whether the California Legislature, at its I965 session, should repeal section 9102(4).

\section{Security Interests in a Retall Merchant's Inventory Under Present California Law}

Various personal property security devices are in use in California, e.g., chattel mortgages, conditional sales, trust receipts, in-

- B.S. 1955, University of Oregon; LL.B. 1959, Harvard University. Associate Professor of Law, University of Oregon; Visiting Associate Professor of Law, Stanford University, 1963-64. The author is indebted to Mr. James T. Caleshu, editor, Stanford Law Review, for valuable research assistance.

1. The California Legislature enacted the 1962 Official Text of the Uniform Commercial Code. Perms. Ed. Bd. For the Uniform Commercinl Code, Report No. 1, at vii (1962 Official Text). This is the fourth text promulgated jointly by the American Law Institute and the Commissioners on Uniform State Laws. The first was promulgated in 1951, the second in 1957, and the third in 1958.

2. Caz. Comis. Code $\$ 9102(4)$.

3. Section 9102(4) reads as follows: "Notwithstanding anything to the contrary in this division, no nonpossessory security interest, other than a purchase money security interest, may be given or taken in or to the inventory of a retail merchant held for sale, except in or to inventory consisting of durable goods having a unit retail value of at least five hundred dollars $(\$ 500)$ or motor vehicles, house trailers, semitrailers, farm and construction machinery and repair parts thereof, or aircraft."

4. These states are Alaska, Arkansas, Connecticut, Georgia, Illinois, Indiana, Kentucky, Maine, Maryland, Massachusetts, Michigan, Missouri, Montana, Nebraska, New Hampshire, New Jersey, New Mexico, New York, Ohio, Oklahoma, Oregon, Pennsylvania, Rhode Island, Tennessee, West Virginia, Wisconsin, and Wyoming.

In 1961 the Oregon Legislature enacted the Code with an amendment prohibiting the creation of security interests in after-acquired inventory. See Summers, Should Oregon Adopt the Uniform Commercial Code Concept of the "Floating Lien"?, 41 ORE. L. REv. 182 (1962). However, at its 1963 session the Oregon Legislature repealed this amendment. 
ventory liens, pledges, and field warehousing, ${ }^{5}$ but the power of a retail merchant to use these devices to create security interests in his inventory is substantially restricted. Under section 2955(3), a chattel mortgage cannot be "made upon ... the stock in trade of a merchant." "The conditional sale, largely a case-law device in California, is not designed to secure loans made against inventory that a retailer has previously acquired, ${ }^{7}$ but designed, instead, to secure the price of goods to be purchased. Trust receipts cannot generally be used to secure loans against previously acquired inventory; their primary use is to secure the repayment of an advance used to acquire inventory. ${ }^{8}$ While the Inventory Lien Law authorizes borrowers to create "continuing liens" on their inventory, ${ }^{9}$ section 3030 (3) thereof provides that "borrower . . . shall not include a retail merchant." $" 10$

California law does not, however, prohibit the creation of all security interests in retail inventory. It appears, though there is no clear authority, that the chattel mortgage or the conditional sale can be used for the limited purpose of creating "purchase money" security interests in inventory, i.e., interests securing payment of the purchase price of inventory. The pledge and its progeny, field warehousing, can be used to create security interests in a retailer's inventory, but retailers seldom use these devices. The pledge requires that the retailer relinquish possession of his inventory; field warehousing necessitates the presence of an independent warehouseman on the premises to "release" inventory to the retailer's customers as sales are made. ${ }^{11}$ The California version of the Uniform Trust Receipts Act ${ }^{12}$ permits the use of trust receipts to secure loans against inventory that a retailer has acquired if the inventory consists of motor vehicles, trailers, semitrailers, aircraft, or durable goods having a per unit value of at least five hundred dollars. ${ }^{13}$ From the retailer's viewpoint, this amendment is the only signifi-

5. The most novel feature of article 9 of the Code, on secured transactions, is its substitution of a unitary security device for the plethora of security devices in use in the various states. See Summers, Secured Transactions Under the Uniform Commercial Code, 42 ORE. L. REv. 1 (1962), 68 CoM. L.J. - (Dec. 1963) (revised).

6. CAz. CIV. CODE $§ 2955(3)$.

7. See Gilmore \& Axelrod, Chattel Security, 57 YaLE I.J. 517, 541 (1948).

8. See UNIFORM TRUST RECEIPTS ACT $\$ 2$.

9. CAL. Civ. COde $\S 3031$.

10. Cal. Civ. Code $\S 3030(3)$. REv. 221.

11. See generally Skilton, Field Warehousing as a Financing Device, 1961 Wis. I.

12. CaI. Crv. Code $\$$ 3012-16.16.

13. CaL. Civ. Code $\S 3014.5$. 
cant departure from the general principle of California law that nonpurchase money security interests cannot be created in retail inventory.

\section{The Impact of Section gio2(4) on Present California Law}

Section 9ro2(4) substantially preserves California law governing the creation of security interests in retail inventories. The amendment provides as follows:

Notwithstanding anything to the contrary in this division, no nonpossessory security interest, other than a purchase money security interest, may be given or taken in or to the inventory of a retail merchant held for sale, except in or to inventory consisting of durable goods having a unit retail value of at least five hundred dollars $(\$ 500)$ or motor vehicles, house trailers, semitrailers, farm and construction machinery and repair parts thereof, or aircraft. ${ }^{14}$

This language embodies a basic prohibition against the creation of a security interest in the inventory of a retail merchant held for sale and three exceptions thereto. The first exception permits creation of "purchase money security interests" in retail inventories. Such interests are defined in section 9-107 of the official text of the Code as follows:

A security interest is a "purchase money security interest" to the extent that it is

(a) Taken or retained by the seller of the collateral to secure all or part of its price; or

(b) Taken by a person who by making advances or incurring an obligation gives value to enable the debtor to acquire rights in or the use of collateral if such value is in fact so used..$^{15}$

Secondly, "possessory security interests" can be created in retail inventories. Although not defined in the Code, presumably "possessory security interests" refers to interests such as those that can be created under existing law by using the pledge or field warehousing. Thirdly, a security interest can be created in certain types of previously acquired retail inventory: "durable goods having a unit retail value of at least five hundred dollars $(\$ 500)$ or motor vehicles, house trailers, semitrailers, farm and construction machinery and repair parts thereof, or aircraft." Although the foregoing basic

14. CaL. Comm. CODE $\S 9102(4)$.

15. Uniforas Commercint Code § 9-107; Cal. Comm. Code $\$ 9107$. 
prohibition and three exceptions substantially preserve existing California law, it should be observed (I) that section 9I02(4), contrary to existing law, makes it clear that purchase money security interests of all kinds may be created in retail inventory and (2) that section 9I02 (4), contrary to section 3014.5 of the California version of the Uniform Trust Receipts Act, does not permit creation of inventory security interests in "trailers" but does permit creation of such interests in "farm and construction machinery and repair parts thereof."

The precise impact of section 9roz(4) on existing California law cannot, however, be ascertained. The amendment includes many important words and phrases such as "retail," "held for sale," "durable goods," and "retail value" for which, understandably, there are no definitions in the Code's elaborate scheme of definitions.

\section{The Effect of Repealing Section 9io2(4)}

The Uniform Commercial Code becomes effective in California on January $x, 1965$. If section 9102 (4) is repealed retailers will then be entitled freely to create security interests in their inventory. Section 9-I02 $(I)(a)^{16}$ allows security interests "in personal property including goods ..."; section 9-109 $9^{17}$ divides "goods" into four classes: "consumer goods," "equipment," "farm products," and "inventory." "Inventory" is further defined as "goods"

held by a person who holds them for sale or lease or to be furnished under contracts of service or if he has leased or so furnished them, or if they are raw materials, work in process or material used or consumed in a business. ${ }^{18}$

Article 9 of the official text not only authorizes the creation of security interests in existing inventory but also permits the creation of a "floating lien," a security interest extending both to inventory owned at the time the loan is made and to inventory acquired thereafter. ${ }^{19}$ Retail merchants expect to "turn their inventory over," to sell from it and to replenish it. Moreover, some retailers are financially unable to repay what they borrow against their inventory from the proceeds of sales as they are made. A creditor who lends to these retailers and takes inventory as security may therefore

16. Uniform Commercial Code § 9-102(1) (a); CaI. Comm. Code § 9102(1)(a).

17. Uniform Commercial Code $\$ 9-109$; CAI. Comm. Code $\$ 9109$.

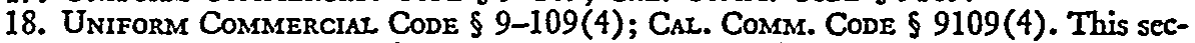
tion also states that "Inventory of a person is not to be classified as his equipment."

19. Uniform Commerciat Code $\$ 9-204$; CAL. Comm. Code $\$ 9204$. 
require that his security interest extend not only to the retailers' existing inventory but also to their after-acquired inventory. One authority has recently observed that a security interest in inventory not extending to after-acquired inventory is "virtually a contradiction in terms." Whether or not this is true, the floating lien assures the inventory financer a constant inventory-to-lien ratio and thus maintains the value of his security. ${ }^{21}$

The Code provisions for the creation of floating liens allow a security agreement to "provide that collateral, whenever acquired, shall secure all obligations covered by the security agreement"22 and permit the use of general descriptions of after-acquired property subject to a security interest: "any description of personal property ... is sufficient whether or not it is specific if it reasonably identifies what is described." ${ }^{\prime 23}$ The infamous doctrine of Benedict v. Ratner ${ }^{24}$ which inhibited the development of the floating lien is also repealed:

A security interest is not invalid or fraudulent against creditors by reason of liberty in the debtor to use, commingle or dispose of all or part of the collateral (including returned or repossessesd goods) or to collect or compromise accounts, contract rights or chattel paper, or to accept the return of goods or make repossessions, or to use, commingle or dispose of proceeds, or by reason of the failure of the secured party to require the debtor to account for proceeds or replace collateral. This section does not relax the requirements of possession where perfection of a security interest depends upon possession of the collateral by the secured party or by a bailee. ${ }^{25}$

Thus, should section 9ro2(4) be repealed after the Code goes into effect, retail merchants will be entitled not only to create security interests in their inventory but also to use the Code's modernized floating lien provisions.

\section{Should the California Legislature Repeal SECTION 9I02(4)?}

In r965, at its next general session, the California Legislature may be asked to repeal section 9ro2(4). What arguments favor

20. Skilton, The Factor's Lien on Merchandise, 1955 WIs. L. Rev. 356, 362.

21. This is true if the debtor replenishes his inventory. See Dunham, Inventory and Accounts Receivable Financing, 62 HARv. L. Rev. 588, 601 (1949).

22. Unifora Comarercial Code \$ 9-204(3); Car. Comm. Code \$ 9204(3). (Emphasis added.)

23. Uniform Commercial Code $\$ 9-110$; Cat. Comm. Code $\$ 9110$.

24. 268 U.S. 353 (1925). See Uniform Commercial Code $\$ 9-205$, comment 1 (OEficial Text 1962).

25. Uniform Comanercial Code $\$ 9-205$; Cat. Comam. Code $\$ 9205$. 
retention of the section, and how may these arguments be answered; what arguments favor its repeal?

\section{A. Arguments Favoring Retention of Section 9ro2(4)}

The amendment purports to preserve the status quo. But the issue, of course, is whether the status quo is worth preserving. Several states enacting the Code had pre-Code restrictions on the borrowing power of retailers comparable to California's, yet none of these states amended the Code to preserve them. ${ }^{28}$ To determine whether section 9ro2(4) should be retained, possible explanations for the origin of laws such as the California statute ${ }^{27}$ prohibiting mortgages on the "stock in trade of a merchant" should be reviewed. First, these statutes may have merely codified early judicial decisions invalidating security interests in retail inventory. ${ }^{28}$ Prior to the enactment of recording statutes, these decisions were understandable. Because a chattel mortgage on inventory allowed the retailer to remain in possession with power to sell, unsecured creditors were afforded no indication that the inventory was encumbered and could plausibly argue that such mortgages ought not to be sanctioned. With the enactment of recording statutes, the plausibility of this argument vanished. Referring to a transaction creating a security interest in inventory, the United States Supreme Court observed in 1890 that

The interests of the general public are not prejudiced by any such transaction. ... The only parties who can claim to be injuriously affected are unsecured creditors. But they are notified by the record of the exact relations between the mortgagor and mortgagee. ${ }^{29}$

The Uniform Commercial Code ${ }^{30}$ requires public filing of security interests in inventory.

A second explanation, and possible justification, for laws restricting the creation of security interests in retail inventory is that to require unsecured creditors periodically to examine public rec-

26. These include Illinois, Davis v. Ranson, 18 Ill. 396 (1857); New Hampshire, Hodgdon v. Libby, 69 N.H. 136, 43 Atl. 312 (1897); Ohio, In re Ackerman, 82 F.2d 971 (6th Cir. 1936).

27. Cal. Civ. Code $\$ 2955(3)$.

28. See Cohen \& Gerber, Mortgages of Merchandise, 39 CoLum. L. Rev. 1338, 1340 (1939).

29. Etheridge v. Sperry, 139 U.S. 266, 277 (1891). See also Williams, Security Interests in Goods, Fixtures, and Equipment of Merchants and Manufacturers, 25 TEXss L. REv. 589, 609 (1947).

30. Uniform Commerctal Code $\S 9-302$; Cax. Comm. Code $\$ 9302$. 
ords is to impose an undue burden on them. ${ }^{31}$ However, unless a careful watch on retail debtors requires significantly more effort than a careful watch on other kinds of debtors, this argument clearly proves too much, for it is an argument against the recognition of any recorded security interest. No evidence indicates that a careful watch on retailers requires more effort, for example more trips to the records, than a careful watch on manufacturers, wholesalers, or other debtors.

Professor Honnold has suggested a third explanation for the early laws prohibiting mortgages on stock in trade:

It seems plausible (though unproved) to suppose that courts and legislatures thought that if a mortgage was "good" it must be good for all purposes, with the result that the lender might be able to take goods away from ordinary customers [who had bought them from the merchant debtor]. This preposterous result has actually been sanctioned by courts on the view that it was a necessary incident of a valid mortgage. ... No wonder there were violent reactions against the institution $]^{32}$

The assumption that a mortgage, to be good at all, must be good for all purposes is fallacious. The Uniform Commercial Code ${ }^{38}$ provides that although a perfected security interest in inventory is generally effective against other creditors, it is ineffective against buyers of inventory in the ordinary course of business.

The foregoing explanations may account for the origin of early laws restricting the borrowing power of retailers, but they do not justify them. Is there any justification for such laws? One justification might be that they effectively immunize some of the retailer's assets from the creation of security interests and thereby reserve them for distribution to unsecured creditors if the retailer becomes insolvent. Unsecured creditors have argued that they are entitled to this reserve because, by extending credit along with secured creditors, they "help keep the retailer in business." ${ }^{34}$ This argument proves too much; it can be advanced against the recognition of any and all security interests. Also, it involves the assumption that laws like section 9ro2(4) somehow guarantee that inventory assets will be available upon insolvency for distribution

31. See Cohen \& Gerber, note 28 supra, at 1341 n.15.

32. Honnold, Cases on Sales and Sales Financing 461-62 n.1 (2d ed. 1962).

33. Uniform Commerctar. Code § 9-307; Caz. Comm. Code $\$ 9307$.

34. See Noble, Tale of Luckless Turtle, 63 Credit \& Financial Management, Feb. 1961, p. 10, at 31-33 (1961). See also Hearings on the Uniform Commercial Code Before the Senate Committee on the Judiciary, 1961 Cal. Legis. Sess. 7. 
to unsecured creditors. This assumption is unwarranted for several reasons, one of which is that even these laws permit an inventory supplier to retain a security interest in the inventory he supplies and each supplier of a particular retailer might create such an interest. Furthermore, no justification has been advanced for favoring unsecured creditors of retailers in a way that unsecured creditors of wholesalers, manufacturers, and other debtors are not favored. In addition, since many unsecured creditors can predict bad debt losses with reasonable accuracy, they can and do protect themselves by taking account of such losses in pricing their products. Finally, unsecured creditors should be encouraged to investigate the credit status of retailers with whom they deal. Laws like section 9ro2(4) may discourage such investigations; some unsecured creditors might decline to investigate, reasoning that there is always inventory available for distribution to unsecured creditors should the debtor become insolvent.

Opposition to the Code concept of the floating lien may account for part of the legislative support of section gro2(4). To permit security interests in the inventory of a retailer is also to permit floating liens in his inventory since the Code validates after-acquired property clauses in security agreements and allows the retailer to remain in full control of his inventory. ${ }^{35}$ The floating lien is not, however, new to California; it has been recognized in chattel mortgage case law ${ }^{86}$ and sanctioned in the recent inventory lien statute. ${ }^{37}$ Some opponents of the floating lien have argued that it is economically objectionable: ${ }^{38}$ under the Code unsecured inventory suppliers risk losing their inventory to holders of prior filed security interests extending to after-acquired inventory, and because of this risk, suppliers may refuse to provide inventory, and businesses may collapse. Yet in Pennsylvania and Massachusetts, where the Code has been in effect for several years, no consequences of this kind have been discerned. ${ }^{30}$ Furthermore, under the Code inventory suppliers can easily establish a security interest in the

35. Uniform Commercial Code $\$ \$ 9-204,9-205$; Cal. Comm. Code $\$ \$ 9204,9205$.

36. In re Los Angeles Mfg. Co., 7 F. Supp. 567 (S.D. Cal. 1933).

37. CAI. Civ. Code $§ 3031$. For the view that the Uniform Trust Receipts Act permits the substantial equivalent of a floating lien see Gilmore, Chattel Security, 57 YALE L.J. 761, 768 (1948).

38. See Noble, supra note 34, at 10,31-33. See also Hearings on the Uniform Commercial Code Before the Senate Committee on the Judiciary, 1961 Cal. Legis. Sess. 12.

39. See text accompanying note 43 infra; note 45 infra. 
inventory they supply ${ }^{40}$ superior to that of all other creditors, prior and subsequent. ${ }^{11}$

Under the Code concept of the floating lien, some have feared that a lender would exact from a hard-pressed merchant a floating lien on all of his assets and, as a result, other creditors would refuse to extend credit to the retailer, forcing him out of business. ${ }^{42}$ This fear is groundless. Since it is in the best interest of the secured creditor that the retailer's business continue, he is not likely to do anything that will put him out of business. Experience in Pennsylvania bears this out. Mr. Warren Kershner, secretary-manager of the Credit Management Association of the Delaware Valley, wrote in $196 \mathrm{I}$ that

While there seems to be some apprehension among non-Code states concerning Article IX with relation to unsecured merchandise creditors, I can truthfully say that in Pennsylvania, our members report no undue advantage of their rights under the Code, and continue to do business on open account with perhaps less fear in some instances than before the Code was adopted. As an example, where accounts receivable financing was prevalent, general creditors were often times unaware of this lien inasmuch as no filing was required.

Presently under the Code, all security agreements must be on record, thus removing any doubt of such secured transactions. While the "floating lien" provision is present under Article IX, this has not been used to any disadvantage of general merchandise creditors using sound judgment. Further, there has been no attempt by general creditors to obtain

40. The supplier must (1) prepare a security agreement describing the type of collateral involved and have his customer sign it, UNIFORM COMMERCIAL CODE $\S 9-203(1)$ (b); Cal. Comar. Code $\$ 9203(1)$ (b); (2) file a financing statement describing the type of collateral involved and setting forth the signatures and addresses of the supplier and his customer, Uniform Commercial Code $\$ 9-402(1)$; Cal. Comm. Code $\$$ 9402(1); and (3) notify prior creditors in accordance with UNIFORM COMMERCiAL CODE $\$ 9-312$ (3)(b); CAL. Comm. Code $\$ 9312(3)$ (b). If he desires, the supplier may use one document both as the security agreement and as the financing statement. UNIForM Comanercial CODE $\$ 9-402$ (1); Cal. COMM. CODE $\$ 9402(1)$. The supplier can then periodically supply inventory without fear that the holder of a prior security interest extending to after-acquired property will acquire a superior security interest in the inventory supplied. However, Coogan has pointed out that "the cautious purchase-money financer will inform the prior filer of the likely extent of his financing and will renew the notice at reasonable intervals." Coogan, Article 9 of the Uniform Commercial Code: Priorities Among Secured Creditors and the "Floating Lien," 72 HARv. L. Rev. 838, 862 n.89 (1959).

41. Uniform Commercial Code \$9-312(3); Cal. Comm. Code \$9312(3). It has been argued that "the possibility of selling on secured credit is not open to most of us who deal in merchandise, supplies, and services that are mingled with the general inventory and are not identifiable or not consumed." Noble, supra note 34, at 32. To this argument it should be said (1) that the Code, unlike the prior law of most states, does not require parties to describe collateral in a detailed way, UnIForM CoMmerciar CODE $\$ 9-110$; CaI. COMm. CODE $\$ 9110$, and (2) that if the collateral loses its identity in a mass, the security interest attaches pro rata to the mass, UNIFORM COMMercinL CODE \$ 9-312(3)(b); CaL. COMM. CODE $\$ 9312(3)$ (b).

42. Hearings on the Uniform Commercial Code Before the Senate Committee on the Judiciary, 1961 Cal. Legis. Sess. 12-13. 
any preference under Article IX. The exercise of such a provision under the Code is readily realized by general merchandise creditors as being economically unreasonable. ${ }^{48}$

Opponents have also argued that adoption of the floating lien stimulates monopoly financing: unscrupulous lenders might unreasonably tie up all of a merchant's assets and thereby exclude other lenders from the field. ${ }^{44}$ Yet one of the premises of this argument is that lending is competitive; since competition does not occur in a vacuum, the lender seeking unreasonable security cannot long compete.

\section{B. Arguments Favoring Repeal of the Amendment}

Not only are the arguments favoring retention of section 9ro2(4) tenuous, but there are also several positive arguments favoring its repeal. First, instead of a bane to unsecured creditors, Code authorization of security interests in retail inventories may be a boon to them. ${ }^{45}$ They may find that under the Code some of their customers who formerly could pay their bills only after sixty, ninety, or 120 days will be able to borrow on their inventory and pay in ten. Unsecured creditors who choose to become secured creditors under the Code will be able to discount indebtedness of their customers and secure earlier payment. Secondly, since inventory is the only significant asset against which some retail merchants might obtain loans, ${ }^{48}$ Code recognition of security interests in inventory should stimulate business activity. Thirdly, since a buyer will be able to give his seller a floating lien in inventory securing payment of the purchase price of a business, ${ }^{47}$ Code

43. The Uniform Commercial Code in Pennsylvania, 1954-1961 (1961).

44. See 1956 N.Y. Law Revision Comm'N ReP. 54-56.

45. On March 29, 1962, the board of directors of the New England Association of Credit Executives passed the following resolution:

"Whereas, the Uniform Commercial Code has been in effect in Massachusetts since October 1, 1958, in New Hampshire since July 1, 1961, and

"Whereas, the Uniform Commercial Code provides a substantially improved body of commercial law as compared to the law which it replaced and this improved law has the benefits of uniformity between the States: and

"Whereas, the New England Association of Credit Executives has not observed any injury to or interference with credit practices or the extension of either secured or general credit but, on the contrary, recognizes improvements in various credit techniques and practices as a result of the enactment of the Uniform Commercial Code in the above states.

"Now, therefore, the New England Association of Credit Executives hereby fully endorses the Uniform Commercial Code as a substantial improvement in the commercial law and recommends its early enactment by all states that have not heretofore done so." Copy on file with Oregon Commissioners on Uniform State Laws.

46. See Skilton, supra note 20 , at 358 .

47. Under the Code without $\$ 9102(4)$, such a security interest could extend to afteracquired inventory as well as to inventory owned at the time of the sale. 
authorization of security interests in the inventory of retail merchants should facilitate transfer of retail businesses. Fourthly, because uniformity in the field of commercial law is becoming increasingly important, the justification for major amendments to the Code should be clear and convincing. The arguments in favor of section 9ro2(4) are not.

Conclusion: Section 9ro2(4) should be repealed. 